DOI https://doi.org/10.30525/978-9934-26-038-4-40

\title{
ОПТИМІЗАЦІЯ РЕПАРАТИВНИХ ПРОЦЕСІВ ПІСЛЯ ДЕСТРУКТИВНИХ МЕТОДІВ ЛІКУВАННЯ КАНАЛУ ШИЙКИ МАТКИ
}

\author{
Шевага О. Я. \\ кандидат медичних наук, \\ асистент кафедри акушерства та гінекологї̈ післядипломної освіти \\ Наиіональний медичний університет імені О. О. Богомольия, \\ завідувач стаиіонару \\ ТОВ «МЕДІКАЛ ІНВЕСТМЕНТ ЕНД ДЕВЕЛОПМЕНТ ГРУП», \\ лікар акушер-гінеколог вищої категорії \\ м. Київ, Україна
}

Шалько М. Н.

кандидат медичних наук,

дочент кафедри акушерства, гінекологї та репродуктології

Начіональний університет охорони здоров'я Украӥни імені П. Л. Шупика,

заступник директора з організачійно-методичних питань КНП «Київський міський центр репродуктивної та перинатальної медицини» виконавчого органу Київської міської ради

(Київської міської державної адміністрачії), лікар акушер-гінеколог вищої категорії

м. Київ, Украӥна

\section{Ковальчук I. В.}

головний спеціаліст Міністерства охорони здоров'я України, очний аспірант вечірньої форми навчання кафедри акушерства, гінекології та репродуктології

Національний університет охорони здоров'я Украӥни

імені П. Л. Шупика

м. Київ, Украӥна

Проблема пошуку удосконалених методів лікування патологій шийки матки (ШМ) набула особливого значення, тому що захворюваність на цервікальний рак зросла, а вік онкохворих «помолодшав» до 20-34 років [1, с. 37-43]. Більшість методик лікування базується на радикальних методах, які забезпечують руйнування (деструкцію) патологічного вогнища 3 наступним відновленням функціонального 
повноцінного багатошарового плоского епітелію, але майже у половини пацієнток виникають стійкі рецидиви та ускладнення.

Найпоширенішими деструктивно-хірургічними методами лікування патологій ШМ є кріодеструкція, електро-(діатермо-)коагуляція, лазерне випромінювання, але найбільш радикальним методом визнано діатермоконізацію (ДЕК) [2, с. 41-44]. Кожен метод має свої показання, протипоказання, ускладнення, переваги та недоліки. Під час застосування цих методів порушується анатомія ШМ й функція зовнішнього вічка (стеноз каналу ШМ, рубцеві зміни ШМ, ендометріоз ШМ, дистоцію ШМ під час пологів, порушення менструальної функції та розвиток істміко-цервікальної недостатності (ІЦН), що негативно впливає на функцію дітонародження [3, с. 51-55].

Анатомічна будова та функція ШМ сприяють процесу запліднення забезпечуючи транспортування сперматозоїдів. Порушення функціональної здатності структур шийки матки виявляються у 2-7\% клінічно здорових жінок і в $15-20 \%$ жінок із гінекологічною патологією $[4$, c. $15-43]$.

Деструктивно-патологічні зміни ШМ зустрічаються переважно у жінок дітородного й працездатного віку, що надає цій проблемі великого соціального значення. Частота цієї патології достатньо велика і в різних країнах коливається від 5 до 18\%. Розповсюдженість деструкцій шийки матки в Україні складає 9\% [5, с. 56-57].

Таким чином, дана патологія $є$ серйозною медико-соціальною проблемою, яка вимагає диференційованої тактики на всіх етапах лікування. Вище викладене спонукає до перспективного пошуку нових методів впливу на перебіг ранового процесу в ШМ після хірургічного лікування.

Мета дослідження: оцінити регенеративну здатність епітелію після деструктивних методів лікування патології шийки матки (ШМ) шляхом місцевого застосування аутоплазми збагаченою тромбоцитами у жінок репродуктивного віку.

На базі КНП «Київського міського центру репродуктивної та перинатальної медицини» було обстежено і проліковано 210 пацієнток репродуктивного віку від 18-45 років, невагітних із цервікальною залозистою інтраепітеліальною неоплазією. Усім пацієнткам було призначено обстеження (цитологічно, бактеріоскопічно, бактеріологічно, на інфекції, що передаються статевим шляхом, проведено діагностику на вірус папіломи людини методом полімеразної ланцюгової реакції, гістологічне дослідження біопсійного матеріалу) та етіопатогенетичне лікування з урахуванням виявлених інфекційних агентів та їхньої чутливості до антибіотиків. Схеми лікування підбирали індивідуально та диференційовано. 
Після нормалізації біоценозу піхви для лікування патології ШМ призначали імуномодулювальні препарати з антивірусною активністю для забезпечення впливу на етіологічний фактор ризику, який призводить до виникнення РШМ - яким є ВПЛ, з наступною кріодеструкцією кріохірургічним апаратом «Кріотон-3» згідно з патентом на корисну модель № 97722 від 25.03.2015 р. «Спосіб лікування плоскоепітеліальної та залозистої інтрацервікальної дисплазії в цервікальному каналі шийки матки».

Усім хворим було проведено лікування відповідно до ступеня тяжкості процесу.

У $80(38,09 \%)$ хворих виконана кріодеструкція ШМ запропонованим методом, у $70(33,33 \%)$ пацієнток проведено ексцизію ШМ ножами Хеймса-Роговенка та у 60 (28,57\%) пацієнток - конусоподібну діатермоелектроконізацію ШМ.

Для покращання епітелізації ШМ після деструктивно-хірургічних методів лікування жінок було поділено на дві групи. Контрольна група жінок отримувала лікування згідно наказу МОЗ України № 236 від 02.04.2014 «Про затвердження та впровадження медико-технологічних документів зі стандартизації медичної допомоги при дисплазії та раку шийки матки». Основній групі жінок було запропоновано місцеве застосування аутоплазми збагаченої тромбоцитами.

В контрольній групі жінок після лікування згідно наказу МО3 України № 236 від 02.04.2014 «Про затвердження та впровадження медико-технологічних документів зі стандартизації медичної допомоги при дисплазії та раку шийки матки» були виявлені деструктивнопатологічні зміни ШМ у вигляді стенозу цервікального каналу ШМ після застосування ексцизії у 14,28\% пацієнток та у 40\% пацієнток після використання ДЕК, а також проведення ДЕК призвело у $20 \%$ до атрезії цервікального каналу ШМ.

У жінок в основній групі яким було запропоновано місцеве застосування аутоплазми збагаченою тромбоцитами після деструктивнохірургічних методів лікування не виявлені деструктивно-патологічні зміни ШМ. Відмічено що епітелізація відбувалася швидше протягом 3 4 тиж, після діатермоелектроексцизії - протягом 5-7 тиж. Слід зазначити, що лише в одному випадку застосування ДЕК призвело до стенозу цервікального каналу ШМ, на фоні запропонованого нами лікування, що говорить про ефективність методу.

Висновок: Дана патологія $є$ серйозною медико-соціальною проблемою, яка вимагає диференційованої тактики на всіх етапах лікування. Вище викладене спонукає до перспективного пошуку нових методів впливу на перебіг ранового процесу в ШМ після хірургічного лікування. 
Місцеве застосування аутоплазми збагаченою тромбоцитами після деструктивних хірургічних методів лікування патології шийки матки дало можливість попердження виникнення деструктивно-патологічних змін на поверхні ШМ, а також зменшило тривалість епітелізації.

\section{Література:}

1. Сгоров О.О. Комплексна діагностика передпухлинних захворювань шийки матки Жіночий лікар. 2010. № 5. С. 37-43.

2. Козуб Н.И., Козуб М.Н. Первый опыт использования радиоволновой энергии при лечении гинекологических больных Междунар. мед. журн. 2010. № 2. С. 41-44.

3. Маршетта Ж., Декамп Ф. Кольпоскопия. М.: МЕДиресс-информ, 2009. $200 \mathrm{c}$.

4. Патология шейки и тела матки: Руководство для врачей / Под ред. проф. Коханевич Е.В. Нежин: Гидро-макс, 2009. 352 с.

5. Хаит Б.М. Криотерапия в лечении доброкачественных заболеваний шейки матки Акушерство и гинекология. 2003. № 4. С. 56-57. 